\author{
Kinga Konieczna \\ Uniwersytet Gdański \\ kinga.konieczna@icloud.com
}

\title{
Glosa do wyroku Sądu Najwyższego z dnia 19 kwietnia 2016 r., II UK $184 / 15$
}

DOI: http://dx.doi.org/10.12775/SIT.2017.021

Tezy wyroku:

1. Przedmiotem umowy o dzieło jest doprowadzenie do weryfikowalnego i jednorazowego rezultatu, zdefiniowanego przez zamawiającego w momencie zawierania umowy. Dzieło jest wytworem, który w momencie zawierania umowy nie istnieje, jednak jest w niej z góry przewidziany i określony w sposób wskazujący na jego indywidualne cechy. Dlatego też jednym z kryteriów umożliwiających odróżnienie umowy o dzieło od umowy zlecenia lub umowy o świadczenie usług jest możliwość poddania dzieła sprawdzianowi na istnienie wad fizycznych. Sprawdzian taki jest zaś niemożliwy do przeprowadzenia, jeśli strony nie określiły w umowie cech i parametrów indywidualizujących dzieło. Taki brak kryteriów określających pożądany przez zamawiającego wynik (wytwór) umowy prowadzi do wniosku, że przedmiotem zainteresowania zamawiającego jest wykonanie określonych czynności, a nie ich rezultat.

2. W przypadku umowy o dzieło autorskie w postaci utworu naukowego (wykładu), przesłanką przedmiotowo istotną (przesądzająca) jest jego zakres, którego wskazanie nie może się ograniczać do danej dziedziny nauki. Istotą wykładu jako dzieła autorskiego jest jego treść zawierająca przekaz określonej myśli intelektualnej 
twórcy, której granice wytycza z góry zamówiony temat. Skoro w momencie zawierania umowy temat wykładu jest nieznany, to nie jest możliwy do ustalenia (zidentyfikowania) jej rezultat.

W ostatnich latach Sąd Najwyższy wiele uwagi poświęcił zagadnieniom rozróżnienia umowy zlecenia, umowy o dzieło i umowy o świadczenie usług w związku $z$ relacją pomiędzy umową o dzieło a prawem autorskim. W glosowanym orzeczeniu analizie poddana została kwestia cyklu wykładów akademickich jako przedmiotu umowy cywilnoprawnej prowadząca do sformułowania tezy, że brak dokładnie określonego tematu umowy uniemożliwia zidentyfikowanie jej jako umowy o dzieło. Duża swoboda w wyborze tematu wykładu, jak również rozłożenie w czasie wynagrodzenia przemawia natomiast na korzyść uznania tej umowy za umowę o świadczenie usług. Prezentowane zagadnienie ma doniosłe znaczenie praktyczne. Umowy o dzieło, których rezultatem jest stworzenie utworu w rozumieniu prawa autorskiego, nie podlegają bowiem, w przeciwieństwie do umów o świadczenie usług obowiązkowemu ubezpieczeniu emerytalnemu, rentowemu i wypadkowemu.

W danej sprawie szkoła wyższa (dalej jako Akademia) wniosła do Sądu Okręgowego odwołanie od decyzji Zakładu Ubezpieczeń Społecznych stwierdzającej, że zainteresowana, pracująca jako nauczycielka akademicka podlegała w okresach wskazanych w decyzji obowiązkowemu ubezpieczeniu emerytalnemu, rentowemu i wypadkowemu jako osoba wykonująca pracę na podstawie umowy zlecenia. Tymczasem Akademia zawarła z zainteresowaną szereg umów nazywanych umowami o dzieło. Ich przedmiotem było prowadzenie wykładów w plenerze oraz warsztatów integracyjnych, a także zajęć dydaktycznych objętych planem studiów w zakresie plastyki i muzyki, w formie wykładów, ćwiczeń i egzaminów oraz warsztatów z dziełami sztuki. Czas trwania zajęć był określony w umowie, miały być one prowadzone na podstawie określonego programu studiów. Sąd Okręgowy w przedmiotowej sprawie przychylił się do stanowiska ZUS. Rozstrzygnięcie poparto stwierdzeniami, że przedmiotem umowy było przekazanie studentom określonej wiedzy w ramach cyklicznych wykładów, nie jest to żaden rezultat ucieleśniony w jakiejkolwiek postaci, a istotą świadczenia zainteresowanej nauczycielki akademickiej jest staranne działanie 
polegające na świadczeniu usług związanych z przekazywaniem wiedzy studentom. Odmienne stanowisko zajął Sąd Apelacyjny, który zmienił zaskarżony wyrok oraz poprzedzającą go decyzję ZUS. $\mathrm{W}$ ocenie sądu umowa łącząca Akademię z zainteresowaną była umową o dzieło, gdyż jej przedmiotem było wygłoszenie wykładu o charakterze niestandardowym i niepowtarzalnym, który nosi znamiona działalności twórczej, jest więc utworem w rozumieniu prawa autorskiego. Od niniejszego rozstrzygnięcia skargę kasacyjną wniósł ZUS. Organ rentowy w skardze kasacyjnej zarzucił naruszenie prawa materialnego poprzez błędne uznanie, że umowy łączące zainteresowaną z Akademią są umowami o dzieło, gdyż ich wykonanie skutkowało powstaniem określonego rezultatu - utworu $\mathrm{w}$ rozumieniu prawa autorskiego. $\mathrm{W}$ ocenie skarżącego prawidłowa wykładnia wskazuje, że były to umowy starannego działania, polegające wyłącznie na przekazywaniu określonej wiedzy, a zainteresowanej nie przysługują do tego nieokreślonego utworu żadne prawa autorskie. Skarga ZUS zawierała także zarzuty naruszenia prawa procesowego w postaci pominięcia dowodów świadczących o powtarzalności, rozciągnięciu w czasie oraz różnorodności czynności zainteresowanej. Sąd Najwyższy przychylił się do stanowiska organu rentowego.

W doktrynie prawa cywilnego wykład definiowany bywa jako niematerialny wytwór intelektu, zawierający treści przekazywane przez wykładowcę studentom ${ }^{1}$. Można stwierdzić, że pojęcie „wykładu” szersze jest od „utworu” w rozumieniu prawa autorskiego. Wobec tego słuszny jest zawarty w glosowanym orzeczeniu pogląd wynikający z wcześniejszego orzeczenia Sądu Najwyższego, że przedmiotem umowy o dzieło może być jedynie wykład spełniający dodatkowe kryteria, tj. wykład o charakterze niestandardowym, niepowtarzalnym, spełniający kryteria twórczego i indywidualnego utworu naukowego ${ }^{2}$. Nie jest jednak w orzecznictwie jednoznaczne, jakie cechy wykładu przesądzają o spełnieniu przez niego wskazanych kryteriów. W niniejszym orzeczeniu Sąd Najwyższy zawarł stwierdze-

1 J.A. Piszczek, Glosa do wyroku Sądu Najwyższego z 27 sierpnia 2013, II UK 25/13, „Przegląd Policyjny” 2015, nr 2, s. 224 i n.

${ }^{2}$ Uchwała SN z dnia 14 lutego 2012 r., III UZP 4/11. 
nie, zgodnie z którym „dla oceny, że zwarto umowę o rezultat usługi (wytwór) konieczne jest, aby działania przyjmującego zamówienie doprowadziły w przyszłości do konkretnego, indywidualnie oznaczonego rezultatu". Tymczasem w przypadku przeprowadzania cyklu wykładów, według oceny Sądu Najwyższego, nie następuje żaden rezultat ucieleśniony w jakiejkolwiek postaci. Przeciwnie - ,jest to wyłącznie staranne działanie wykonawcy umowy, który stosownie do posiadanej wiedzy ma ją przekazać studentom”. Za kwalifikacją umowy jako umowy o świadczenie usług przemawia więc niedostatecznie określone w umowie cech i parametrów dzieła i w związku z tym dzieło nie może stanowić odrębnego przedmiotu obrotu. Wykład, który nie został utrwalony, nie posiada tego przymiotu (tzn. nie jest odrębnym przedmiotem obrotu). Mieści się natomiast w pojęciu usługi ${ }^{3}$. Argument ten może budzić wątpliwości - taka umowa może przecież prowadzić do rezultatu niematerialnego, ale sprawdzalnego, np. na podstawie realizacji programu zajęć określonego w sylabusie ${ }^{4}$. Ponadto należy zwrócić uwagę, że ścisłe określenie rezultatu w przypadku umowy o dzieło, której przedmiotem byłby utwór mogłoby powodować, że osoby trzecie partycypowałyby w tworzeniu utworu naukowego, narzucając mu określone wymagania. Nie zawsze zatem stworzenie przedmiotu prawa autorskiego jest obiektywnie możliwe, a subiektywnie pewne ${ }^{5}$.

Zdaniem Sądu wygłoszenie cyklu wykładów sprowadza się wyłącznie do prezentacji wiedzy przy zastosowaniu standardowych metod i procedur przekazu, co przesądza o zakwalifikowaniu umowy w przedstawionym stanie faktycznym jako umowy o świadczenie usług. Aby dokonać oceny prawidłowości tej tezy, warto najpierw rozważyć istotę umowy o dzieło. Zgodnie $z$ art. 627 kodeksu cywilnego do elementów przedmiotowo istotnych tej umowy należy zobowiązanie przyjmującego zamówienie do wykonania oznaczonego dzieła oraz ekwiwalentne zobowiązanie zamawiającego do zapłaty

${ }^{3}$ L. Ogiegło, Pojęcie usługi $i$ umów o świadczenie usług $w$ ujęciu kodeksu cywilnego, „Studia Iuridica Silesiana” 1979, t. V, s. 141 i n.

${ }^{4}$ M. Wałachowska, w: Umowy cywilnoprawne $w$ ubezpieczeniach społecznych, red. M. Szabłowska-Juckiewicz, M. Wałachowska, Jacek Wantoch-Rekowski, Warszawa 2015, s. 172 i n.

5 Ibidem, s. 173. 
wynagrodzenia. Tym, co odróżnia umowę o dzieło od innych umów, jest przede wszystkim brak podporządkowania, jakkolwiek przyjmujący zamówienie może udzielać wskazówek co do tego, jak dzieło ma wyglądać ${ }^{6}$. Natomiast zgodnie $z$ kodeksem cywilnym w przypadku zlecenia zleceniobiorca powinien w zasadzie wykonać zlecenie osobiście i stosować się do wskazanego przez zleceniodawcę sposobu wykonania zlecenia, co odróżnia tę umowę od umowy o dzieło ${ }^{7}$. Przy umowie zlecenia inaczej określono też przedmiot świadczenia polegający na dokonaniu czynności prawnej. Samo staranne działanie zleceniobiorcy i mimo to nieosiągnięcie zamierzonego rezultatu nie stanowi przypadku niewykonania zobowiązania ${ }^{8}$. W związku z przedstawionymi rozważaniami należy stwierdzić, iż teza zawarta w glosowanym rozstrzygnięciu Sądu Najwyższego zasadniczo zasługuje na aprobatę, jednak kwalifikacji umowy należałoby dokonywać ad casum, uwzględniając każdorazowo okoliczności danej sprawy. Wykłady nie stanowią bowiem jednorodnej kategorii. Sąd Najwyższy zdaje się natomiast arbitralnie zakładać, że każdy wykład polegający wyłącznie na prezentacji wiedzy $z$ danej dziedziny przy użyciu standardowych procedur i metod przekazu jest wyłącznie świadczeniem usług nie prowadzi natomiast do żadnego konkretnego rezultatu. Takie stanowisko mogłoby prowadzić do krzywdzących konsekwencji dla twórców wykładów prezentujących, którzy nie mogliby wówczas czerpać korzyści z tworzonych utworów, np. poprzez sprzedaż książek czy innych ich nośników materialnych.

Pozytywnie oceniam zwrócenie przez Sąd Najwyższy uwagi na charakter prawny rezultatu umowy o dzieło, który co do zasady powinien mieć charakter jednorazowy. W przedstawionym stanie faktycznym strony zawarły umowę o stworzenie i przeprowadzenie przez zainteresowaną cyklu wykładów i warsztatów. Powtarzalność tej czynności oraz przygotowanie materiałów w oparciu o ramowy

${ }^{6}$ R. Longchamps de Berier, Zobowiazania, oprac. J. Górski, Poznań 1948, s. 559.

7 K. Kołakowski, w: Komentarz do kodeksu cywilnego. Księga trzecia. Zobowiązania, tom II, red. G. Bieniek, H. Ciepła, S. Dmowski, J. Gudowski, K. Kołakowski, M. Sychowicz, T. Wiśniewski, C. Żuławska, Warszawa 2011, s. 532.

${ }^{8}$ K. Zagrobelny, w: Kodeks cywilny. Komentarz, red. E. Gniewek, P. Machnikowski, Warszawa 2016, s. 1257. 
program studiów może prowadzić do wniosku, że celem umowy nie było zaspokojenie zainteresowania zamawiającego określonym utworem intelektualnym, lecz raczej prezentacja słuchaczom wiedzy $z$ danej dziedziny. Należy także zauważyć, że argument przemawiający przeciwko kwalifikacji wykładu jako przedmiotu umowy o dzieło mogą stanowić też sformułowania językowe, którymi ustawodawca posłużył się w przepisach dotyczących umowy o dzieło. Rezultat tej umowy musi nadawać się do „oddania” (zgodnie $z$ art. 642 § 2 k.c.) i „wydania” (art. 636 § 2 k.c.). W przypadku nieucieleśnionego ustnego wykładu problematyczna może być zarówno kwestia wydania dzieła, jak i kwestia rękojmi za wady (nie może on podlegać np. naprawie).

Rację ma Sąd Najwyższy, prezentując stanowisko, że z celu umowy określonego jako „edukacja studentów” nie może wynikać obiektywny i osiągalny rezultat. Taki efekt nie jest bowiem w pełni zależny od świadczenia wykładowcy. Nie powoduje to jednak całkowitej niedopuszczalności stosowania konstrukcji umowy o dzieło do świadczeń edukacyjnych. Dzieło powinno wówczas zostać oznaczone jako zaprezentowanie wykładu wraz z odpowiednim przygotowaniem materialnych i sprawdzalnych materiałów dydaktycznych $z$ nim związanych. $Z$ analizy stanu faktycznego w sprawie wynika ponadto, że strony dokonały w umowie rozróżnienia na przedmiot umowy (świadczenie) w postaci zachowania oraz jego rezultat (dzieło) ${ }^{9}$. Ich intencją było więc zawarcie umowy o dzieło, mimo niezbyt trafnego określenia jej przedmiotu. Co więcej, zainteresowana zobowiązana była do sporządzenia programu zajęć, który następnie podlegał weryfikacji kierownika studiów w oparciu o zgodność ze standardami ramowymi studiów. Taki program obejmujący ramowe zagadnienia w zupełności może być uznany za materialny obiekt - przedmiot świadczenia, do którego możliwe jest zastosowanie przepisów kodeksu cywilnego stanowiących o wydaniu dzieła czy rękojmi za wady (można np. domagać się jego poprawienia).

Zasadniczo na aprobatę zasługuje również zawarte w glosowanym wyroku Sądu Najwyższego stanowisko, zgodnie z którym na

9 T. Dybowski, w: System prawa cywilnego. Zobowiąania - część ogólna, t. III, cz. 1, red. Z. Radwański, Wrocław 1981, s. 71 i n. 
rzecz kwalifikacji danej umowy jako umowy o świadczenie usług przemawia sposób określenia wynagrodzenia. Zgodnie $z$ regulacją zawartą $\mathrm{w}$ kodeksie cywilnym, wynagrodzenie $\mathrm{z}$ umowy o dzieło powinno być bowiem określane $\mathrm{w}$ sposób ryczałtowy lub kosztorysowy. Natomiast w przedstawionym stanie faktycznym strony stosowały jednolite stawki wynagrodzenia za działanie rozłożone w czasie. Mogłoby to potwierdzać, że intencją stron nie było zawarcie umowy o wykonanie dzieła, lecz powtarzalnej pracy za ustalonym w jednostkach czasowych wynagrodzeniem. Należy zarazem mieć na uwadze, że przedstawione stanowisko mogłoby być przedmiotem polemiki $z$ uwagi na to, że w niniejszym stanie faktycznym zastosowanie mógłby znaleźć także art. 642 kodeksu cywilnego, który dopuszcza możliwość oddawania dzieła częściami oraz zapłaty wynagrodzenia za każdą część $z$ osobna.

Należy także zauważyć, że Sąd Najwyższy stwierdzając w glosowanym orzeczeniu, że umowa o stworzenie cyklu wykładów nie ma charakteru twórczego, lecz raczej odtwórczy, odbiega od liberalnych stanowisk przedstawianych $\mathrm{w}$ poprzednich orzeczeniach związanych $z$ danym tematem. W tezie orzeczenia $z$ 25.05.2011 r. zawarto bowiem stwierdzenie, że „charakter twórczy może mieć nawet usunięcie $z$ utworu naukowego niektórych tez, podyktowane względami merytorycznymi" ${ }^{10}$. W innym uzasadnieniu orzeczenia zawarto natomiast pogląd, że wygłoszenie cyklu wykładów traktujących o jednym konkretnym zagadnieniu, przedstawienie określonej problematyki lub wyczerpanie zagadnienia ujętego w tytule, który ma cechy utworu w pojęciu art. 1 ust. 1 ustawy o prawie autorskim i prawach pokrewnych może mieć znamiona „działalności twórczej”, $\mathrm{w}$ rozumieniu prawa autorskiego ${ }^{11}$. Tymczasem ustawa o prawie autorskim i prawach pokrewnych definiuje utwór bardzo szeroko jako każdy przejaw działalności twórczej o indywidualnym charakterze, ustalony w jakiejkolwiek postaci, niezależnie od wartości, przeznaczenia i sposobu wyrażenia. W późniejszych orzeczeniach pogląd ten był podzielany i kontynuowany poprzez stwierdzenia, że rezultatem umowy może być utwór w postaci wykładu, od warun-

\footnotetext{
${ }^{10}$ Wyrok SN z dnia 25 maja 2011, II CSK 527/10, Lex nr 794636.

11 Wyrok SN z dnia 27 sierpnia 2013, II UK 26/13, Lex nr 1379926.
} 
kiem, że zdatny jest on do sprawdzenia pod kątem wad fizycznych oraz, że dziełem w takim przypadku nie jest czynność, lecz wynik czynności ${ }^{12}$. Za utwory w orzecznictwie polskich sądów bywały też uznawane czynności takie jak recytacja wiersza czy ułożenie twórczości polskiej poetki w porządku chronologicznym. W związku z zaprezentowanymi stanowiskami Sądu Najwyższego należy poddać głębokiej refleksji okoliczność, czy na uznanie za utwór nie zasługują np. poglądy autora przedstawiane na wykładach, opracowywane przez niego materiały czy porządek prezentacji treści programowych oraz kwestię wytyczenia granicy pomiędzy wykładem o charakterze odtwórczym a aktem twórczym. Wydaje się, wbrew koncepcji przedstawionej w glosowanym orzeczeniu, że duża swoboda w wyborze tematu nie przesądza o braku indywidualnego i twórczego charakteru dzieła. Takie rozumowanie wydaje się uproszczone, a koncepcja może sięgać zbyt daleko, w efekcie pozbawiając autorów wykładów stworzonych według własnego i oryginalnego pomysłu prawnej ochrony dobra osobistego w postaci twórczości naukowej, jak również ochrony, którą przyznaje utworom ustawa o prawie autorskim (np. przed plagiatem).

Jako że problematyka kwalifikacji wykładu jako przedmiotu umowy niejednokrotnie okazała się w orzecznictwie polskich sądów problematyczna, warto w tej kwestii odwołać się do analizy prawnoporównawczej. Zgodnie z poglądami francuskiej doktryny, przedstawionymi w wypowiedzi prof. Andre Françona $z$ Uniwersytetu Paris II, wykład jest utworem słownym (przedmiotem prawa autorskiego). Takie zapatrywanie dominuje w poglądach nauki francuskiej ${ }^{13}$. Również w praktyce uczelni amerykańskich (jak np. Uniwersytet Harvarda) w sposób niekwestionowany przyjmuje się, że w wyniku wykonywania obowiązków pracowniczych, zarówno przez nauczycieli akademickich, jak i przez osoby niebędące nauczycielami akademickimi, powstają utwory, a ze sprzedaży książek i innych materialnych ich nośników autor może czerpać korzyści (kwestią problematyczną bywa jedynie, do kogo należą prawa autorskie, gdy

\footnotetext{
${ }_{12}$ Wyrok SN z dnia 4 czerwca 2014, II UK 420/13.

13 A. Françon, Cours de propriété littéraire, artistique et industrielle, Paris 1989, s. 173.
} 
utwory tworzone są przez osoby niebędące pracownikami uczelni, czy w przeważającej mierze $z$ wykorzystaniem dostarczonych przez nią środków) ${ }^{14}$. Również doktryna niemiecka wydaje się stać na stanowisku, że wykład jako przedmiot komunikacji społecznej ujawniający zapatrywania czy preferencje autora powinien być postrzegany jako działalność twórcza. W tym kontekście autorowi przysługuje szereg osobistych praw podmiotowych do utworu. Niemiecka ustawa o prawach autorskich zastrzega na jego rzecz m.in. prawo do publicznego ujawnienia czy opisania zawartości utworu oraz do decydowania, czy i w jaki sposób będzie on publikowany ${ }^{15}$.

Nie można nie zauważyć, że polskie sądy nie są jednolite w dokonywaniu interpretacji utworu w rozumieniu prawa autorskiego jako przedmiotu umowy o dzieło. Wpływa to na zmniejszenie ochrony prawnej przysługującej autorom wykładów oraz brak pewności prawnej w przedstawionej kwestii, który jest zjawiskiem bardzo niekorzystnym, zwłaszcza w orzecznictwie Sądu Najwyższego.

W konkluzji stwierdzam, że argumentacja Sądu Najwyższego w glosowanym orzeczeniu jest w dużym stopniu racjonalna i trafna, jednak ostateczne rozstrzygnięcie wymaga weryfikacji oraz bardziej wnikliwego przyjrzenia się wspomnianej problematyce. Stworzenie cyklu wykładów jako wytworu intelektu powinno być, wzorem poglądów doktryny innych państw, uznawane ze utwór podlegający ochronie prawa autorskiego i w konsekwencji podlegać reżimowi umowy o dzieło. Wykluczenie takiej możliwości byłoby nie tylko nieuzasadnione teoretycznie, lecz także może powodować niekorzystne skutki w praktyce obrotu.

\footnotetext{
${ }^{14}$ M. Salamonowicz, Prawna regulacja komercjalizacji własności intelektualnej publicznych szkół wyższych, Warszawa 2016, s. 55.

15 Ibidem, s. 110.
} 